\title{
Hisab Urfi Gerhana Matahari Dan Gerhana Bulan
}

\author{
Is mail ${ }^{*}$ \\ Dosen Jurusan Ilmu Falak Fakultas Syariah IAIN Lhokseumawe. \\ "email : ismail@iainlhokseumawe.ac.id
}

\begin{abstract}
$\overline{\text { Solar eclipse and lunar eclipse are astronomical events that }}$ have become religious education events for Indonesian Muslim communities, this can be seen in the total solar eclipse on March 9, 2016 and ring solar eclipse on December 26, 2019, where all regions in Indonesia observe and pray eclipse in congregation. The ease in getting information about eclipse events resulted in the easy mobilization of people to get involved in every eclipse event. This ease of information makes ordinary people feel as if eclipses have often occurred in the last few years. This paper tries to narrate a brief way of knowingsolar and lunar eclipses in reckoning every Hijri year.
\end{abstract}

Keywords: Islamic Astronomy, Hisab Urfi, Eclipse.
Artikel Info

Received:

10 Maret 2020

Revised:

27 Maret 2020

Accepted:

08 April 2020

Published:

02 Juni 2019

\section{Abstrak}

Gerhana matahari dan gerhana bulan merupakan peristiwa astronomis yang sudah menjadi peristiwa edukasi religius bagi masyarakat muslim Indonesia, hal ini bisa dilihat pada peristiwa gerhana matahari total 9 Maret 2016 dan gerhana matahari cincin 26 Desember 2019, dimana semua wilayah di Indonesia melakukan pengamatan dan salat gerhana secara berjamaah. Kemudahan dalam mendapatkan informasi peristiwa gerhana mengakibatkan mudahnya mobilisasi masyarakat untuk ikut terlibat dalam setiap peristiwa gerhana. Kemudahan informasi ini membuat masyarakat awam merasakan seolah-olah gerhana sudah sering terjadi dalam beberapa tahun terahir. Tulisan ini mencoba menarasikan secara singkat cara mengetahui gerhana matahari dan bulan secara hisab urfi dalam setiap tahun Hijriah.

Kata Kunci : Ilmu Falak, Hisab Urfi, Gerhana.

\section{A. Pendahuluan}

Fenomena gerhana sudah menjadi peristiwa religius yang selalu ditunggutunggu oleh publik. Setiap peristiwa gerhana terjadi, informasi selalu diberitahukan jauh-jauh hari sebelum peristiwa terjadi dan informasi ini dikonsumsikan oleh semua kalangan. Dari satu sisi, kemudahan informasi ini mampu mencerdaskan masyarakat dari pembodohan mitos masa lalu. Kecerdasan masyarakat dalam menyikapi peristiwa gerhana dapat 


\section{AL-MARSHAD: JURNAL ASTRONOMI ISLAM DAN ILMU-ILMU BERKAITAN \\ ISSN 2442-5729 (print) || ISSN 2598-2559 (online) \\ http://jurnal.umsu.ac.id/index.php/almarshad \\ DOI: $10.30596 /$ jam.v\%vi\%i.4411 || Vol. 6, No. 1. Juni 2020}

dilihat dalam buku laporan LAPAN terhadap pengamatan gerhana matahari tota19 Maret 2016. ${ }^{1}$

Gerhana matahari total ini menjadi gerbang dan jendela ilmiah pemahaman masyarakat Indonesia, tidak ditemukan pelarangan terhadap pengamatan gerhana saat itu, bahkan ada anjuran untuk melaksanakan salat gerhana sejara berjamaah dari Kementerian Agama Republik Indonesia.

Dari sisi lain, kemudahan informasi tersebut menimbulkan pemahaman baru bagi masyarakat Indonesia, dimana seolaholah peristiwa gerhana sudah memasuki periode yang tidak lazim lagi, yaitu peristiwa gerhana sudah mulai sering terjadi tidak seperti zaman dahulu dan tidak sedikit yang mengaitkan gerhana dengan peristiwa kiamat. Tulisan ini mencoba menawarkan cara mudah untuk mengetahui jumlah peristiwa gerhana dalam setiap tahun Hijriah dengan pendekatan hisab urfi. Tujuan dari penggunaan metode hisab urfi ini agar memudahkan semua kalangan yang berminat untuk mengetahui jumlah gerhana matahari dan bulan yang akan terjadi dalam setiap tahun.

Selama ini sudah banyak tulisan

${ }^{1}$ LAPAN, The Eclipse Gerhana Matahari Total (Catatan Peristiwa 9 Maret 2016) (Jakarta: LAPAN, 2016). yang membahas tentang gerhana, seperti tulisan Siti Lailatul Mukarromah ${ }^{2}$ (2019) yang membahas cara mengetahui gerhana matahari dengan menggunakan algoritma NASA. Tulisan Muhajir ${ }^{3}$ (2019) juga membahas tentang hisab gerhana bulan dalam kitab Nur Al-Anwar. Tulisan Ehsan Hidayat ${ }^{4}$ (2019) tentang cara menghitung jumlah terjadi gerhana dengan argumen lintang bulan dan teori aritmatika. Dan tulisan Muhammad Farid Azmi, Dkk. ${ }^{5}$ (2018) Juga menjelaskan cara hisab gerhana bulan dengan menggunakan data ephemeris hisab rukyat. Semua tulisan tersebut tergolong berat bagi pemula, hanya bisa dipahami oleh yang sudah membidangi. Kiranya tulisan "Hisab urfi gerhana matahari dan bulan" menjadi penting untuk dikaji dan didalami dalam rangka membumikan ilmu falak di Indonesia.

\section{Fisis Gerhana Matahari dan Gerhana} Bulan

Salah satu cara melepaskan ikatan

${ }^{2}$ Siti Lailatul Mukarromah, "Perhitungan Gerhana Matahari Dengan Algoritma NASA," Ulul Albab: Jurnal Studi Dan Penelitian Hukum Islam 2, no. 2 (19 Juli 2019): h. 99-113,

${ }^{3}$ Muhajir Muhajir, "Sistem Hisab Gerhana Bulan Kh. Noor Ahmad SS Dalam Kitab Nûr AlAnwâr," Jurnal Islam Nusantara 3, no. 2 (29 Desember 2019): h. 456-75,

${ }^{4}$ Ehsan Hidayat, "Penentuan Jumlah Gerhana Matahari Dengan Argumen Lintang Bulan Dan Teori Aritmatika," Miyah: Jurnal Studi Islam 15, No. 01 (12 September 2019): h. 12-42.

${ }^{5}$ Muhammad Farid Azmi, "Prediksi Pergerakan Bayangan Bumi Saat Terjadi Gerhana Bulan Menggunakan Ephemeris Hisab Rukyat," Al-Marshad: Jumal Astronomi Islam dan Imu-Ilmu Berkaitan 4, no. 2 (1 Desember 2018). 


\section{AL-MARSHAD: JURNAL ASTRONOMI ISLAM DAN ILMU-ILMU BERKAITAN \\ ISSN 2442-5729 (print) || ISSN 2598-2559 (online) \\ http://jurnal.umsu.ac.id/index.php/almarshad \\ DOI: 10.30596/jam.v\%vi\%i.4411 || Vol. 6, No. 1. Juni 2020}

pemahaman manusia dari cengkraman mitos tentang gerhana adalah memahami peristiwa gerhana secara fisis. Fis is gerhana matahari dan bulan hanya dapat dipahami dengan pendekatan ilmiah. Dalam dunia Islam, mitologi seputar gerhana telah dihapus oleh Rasullah Saw. saat menyikapi gerhana matahari cincin yang terjadi bersamaan dengan meninggalnya Ibrahim anak nya. Rasulullah secara tegas menepis mitos masyarakat Arab waktu itu yang meyakini gerhana matahari yang terjadi saat itu karena wafatnya Ibrahim, Rasulullah menjelaskan bahwa gerhana itu murni tanda kekuasaan Allah Swt. bukan karena meninggal seseorang atau hidupnya seseorang. ${ }^{6}$ Pemahaman manusia sebagai mikro kosmos bukan berarti peristiwa dalam makro kosmos mampu mempengaruhi nasib baik dan buruk dalam mikro kosmos manusia. Makna mikro kosmos manusia dalam konteks gerhana adalah bagaimana manusia sebagai makhluk harus ikut tunduk dan patus terhadap sang pencipta sebagaimana makhluk yang lain seperti bumi, bulan, dan matahari yang selalu patuh terhadap

\footnotetext{
${ }^{6}$ Ahmad Ainul Yaqin dan Fahmi Fatwa Rosyadi Satria Hamdani, "Hadis Gerhana Dan Wafatnya Ibrahim Ibn Muhammad," Tahkim (Jumal Peradaban dan Hukum Islam) 1, no. 1 (15 Maret 2018)
}

ketentuan sang pencipta. $^{7}$

Secara temuan ilmiah memang ada pengaruh saat peristiwa gerhana dengan kehidupan di permukaan bumi, seperti melambatnya gravitasi bumi, ${ }^{8}$ perubahan perilaku ayam saat gerhana matahari karena mengira sudah malam, ${ }^{9}$ dan perubahan gerak daun yang biasa terbuka dan tertutup akibat siang dan malam. ${ }^{10}$ Semua itu terjadi perubahan terhadap fisik benda, tidak ada perubahan pada nasib ayam, sakit dan buta misalnya dan juga tidak berakibat kering daun dan mati pohon yang terkena sinar matahari saat gerhana terjadi. Gerhana juga bukan menjadi sebuah tanda akan perubahan nasib, misalnya akan terjadi pertumpahan darah setelah gerhana bulan total terjadi atau akan datang kemenangan setelah peristiwa gerhana matahari terjadi.

Secara sederhana gerhana dapat didefinisikan sebagai peristiwa terhalang sinar

${ }^{7}$ Rusydi Sulaiman, "Gerhana Dan Keharusan Kosmologis Manusia: Tinjauan Filsafat Wujud," Edugama: Jurnal Kependidikan Dan Sosial Keagamaan 3, no. 2 (31 Desember 2017): h. 104-26,

${ }^{8}$ Toni Kus Indratno, Ginanjar A. Muhammad, dan Widiyaka Adinugraha, "Penganuh Gerhana Matahari Terhadap Nilai Percepatan Gravitasi Bumi: Sarana Pembelajaran untuk Mendekatkan Fisika pada Kehidupan Sehari-hari" 3, no. 1 (2016): h. 10-12.

${ }^{9} \mathrm{M}$ Ilham, Hendro Moro, dan Dahlan, "Perilaku Ayam Mutiara (Numida melegris, Linn 1758) pada saat Gerhana Matahari Sebagian di Jogjakarta," 17 Agustus 2016.

${ }^{10}$ Muhammad Najib Alyasyfi dkk., "Pengaruh Perubahan Intensitas Cahaya Akibat Gerhana Matahari Sebagian Temadap Gerak Daun Bauhinia Purpurea," Prosiding Seminar Nasional Fisika (E-Journal) 5 (30 Oktober 2016): h. 39-44, 


\section{AL-MARSHAD: JURNAL ASTRONOMI ISLAM DAN ILMU-ILMU BERKAITAN \\ ISSN 2442-5729 (print) || ISSN 2598-2559 (online) \\ http://jurnal.umsu.ac.id/index.php/almarshad \\ DOI: $10.30596 /$ jam.v\%vi\%i.4411 || Vol. 6, No. 1. Juni 2020}

matahari, gerhana matahari terjadi karena terhalang sinar matahari sampai ke bumi oleh piringan bulan dan gerhana bulan terjadi akibat terhalang sinar matahari sampai ke bulan oleh bumi. Dalam ilmu falak, untuk gerhana matahari dikenal dengan sebuah peristiwa dimana piringan matahari ditutupi oleh piringan bulan yang dikenal dengan istilah kusuf (menutupi). Sedangkan untuk gerhana bulan dikenal dengan sebuah peristiwa dimana bulan memasuki bayangan kerucut bumi yang dikenal dengan istilah khusuf (memasuki). ${ }^{11}$ Gerhana bulan atau gerhana matahari akan terjadi bila sudah memenuhi 3 syarat:

1. Bayangan (bulan atau bumi) harus lebih panjang dari jarak bulan ke bumi.

2. Bulan dan matahari harus berada pada posisi konjungsi (bulan mati) atau oposisi (bulan purnama).

3. Bulan harus berada pada garis simpul atau pada jarak tertentu dari garis simpul. $^{12}$

Dalam ilmu astronomi dikenal ada 4 jenis gerhana matahari:

${ }^{11}$ Fahmi Fatwa Rosyadi Satria Hamdani, Encep Abdul Rojak, dan Maulan Rif'atul Wafy, "Fikih Salat Gerhana Menurut Imam Ibnu Hajar AlHaitami," Al-Marshad: Jurnal Astronomi Islam Dan Ilmu-Ilmu Berkaitan 5, no. 1 (3 Juni 2019).

${ }^{12}$ M. Yusuf Harun, Pengantar Ilmu Falak (Banda Aceh: PeNA, 2008). h. 106
1. Gerhana matahari total. Dinamakan dengan total bila saat puncak gerhana seluruh piringan matahari ditutupi oleh piringan bulan.

2. Gerhana matahari parsial atau sebagian. Dinamakan gerhana matahari parsial bila saat puncak gerhana terjadi piringan matahari hanya sebagian ditutupi oleh piringan bulan.

3. Gerhana matahari cincin. Dinamakan dengan gerhana matahari cincin bila saat puncak gerhana hanya piringan tengah matahari yang tertutup oleh piringan bulan, sehingga lingkaran pinggiran piringan matahari masih bersinar menyerupai cincin.

4. Gerhana matahari hibrid. Dinamakan dengan gerhana ini bila saat puncak gerhana di satu wilayah terlihat dalam bentuk cincin, sedangkan di wilayah lain terlihat dalam bentuk total. ${ }^{13}$

Untuk gerhana bulan hanya dikenal 3 jenis saja, yaitu:

1. Gerhana bulan total. Dinamakan dengan gerhana bulan total bila saat puncak gerhana bulan sepenuhnya masuk dalam bayang kerucut umbra bumi sehingga warna bulan terlihat hitam kemerahmerahan.

\footnotetext{
${ }^{13}$ Alimuddin Alimuddin, "Gerhana Matahari Di Abad 21," Al Daulah : Jurnal Hukum Pidana Dan Ketatanegaraan 5, no. 2 (15 Desember 2016): h. 42743.
} 


\section{AL-MARSHAD: JURNAL ASTRONOMI ISLAM DAN ILMU-ILMU BERKAITAN ISSN 2442-5729 (print) || ISSN 2598-2559 (online) \\ http://jurnal.umsu.ac.id/index.php/almarshad \\ DOI: $10.30596 /$ jam.v\%vi\%i.4411 || Vol. 6, No. 1. Juni 2020}

2. Gerhana bulan parsial. Disebut dengan gerhana parsial bila saat puncak gerhana terjadi bulan hanya me masuki sebagian bayang kerucut umbra bumi sehingga setengah piringan bulan terlihat berwarna hitam.

3. Gerhana bulan penumbra. Gerhana bulan penumbra merupakan sebuah peristiwa dimana bulan hanya memasuki bayangan penumbra bumi. Secara kasat mata bulan hanya terlihat sedikit redup sinarnya ketimbang saat purnama-purnama biasanya. ${ }^{14}$

Keteraturan orbit bumi dan bulan dalam mengintari pusat orbit dan bentuk orbit yang selalu tetap, mengindikasikan bahwa peristiwa gerhana matahari dan bulan sudah ada semenjak matahari, bumi, dan bulan ada. Menarasikan peristiwa gerhana matahari dan bulan sebagai peristiwa langka atau hanya ahir-ahir ini gerhana sudah sering terjadi termasuk pembodohan dan tidak ilmiah. Secara fakta, dalam satu tahun minimal wajib ada empat kali gerhana, yaitu dua kali gerhana matahari dan dua kali gerhana bulan dan maksimal atau paling banyak 7 kali terjadi gerhana seperti yang pernah terjadi pada tahun 1982 (4 gerhana matahari dan 3

\footnotetext{
${ }^{14}$ Qomaruz Zaman, "Gerhana Dalam Perspektif Hukum Islam Dan Astronomi," Empirisma: Jurnal Pemikiran Dan Kebudayaan Islam 25, no. 2 (2 November 2016).
}

gerhana bulan), hanya saja lokasi terlihat gerhana di permukaan bumi yang tidak wajib sama dalam setiap tahun. Boleh jadi di tahun ini tidak terlihat gerhana di Indonesia, namun ada terlihat di wilayah lain. Dalam satu tahun bisa juga terjadi 5 kali gerhana matahari, seperti yang pernah terjadi pada tahun 1805 , 1935 dan akan terjadi di tahun 2206 dan lima kali gerhana bulan, seperti yang pernah terjadi pada tahun 1676, 1694, 1749, dan akan terjadi pada tahun 2132. ${ }^{15}$ Jadi, peristiwa gerhana matahari dan gerhana bulan bukan peristiwa langka dan bukan hanya ahir-ahir ini yang sering terjadi, sepantasnya peristiwa langka boleh dinarasikan untuk peristiwa transit venus dan merkurius.

\section{B. Metode Penelitian}

Penelitian ini termasuk dalam penelitian kepustakaan (library research) ${ }^{16}$, yaitu penulis berbicara banyak dengan bukubuku, arsip-arsip, dokumen-dokumen, dan catatan-catatan.Jenis penelitian ini adalah kualitatif dengan pendekatan deskriptif analitik. ${ }^{17}$

\section{Hasil Dan Pembahasan}

\section{Hisab Urfi Ge rhana Bulan}

Gerhana bulan merupakan sebuah

\footnotetext{
${ }^{15}$ Rinto Anugraha, Mekanika Benda Langit (Yogyakarta: MIPA UGM, 2012). h. 128-130.

${ }^{16}$ Bungaran Antonius Simanjuntak dan Soedjito Sosrodihardjo, Metode Penelitian Sosial, (Jakarta: Yayas an Pus taka Obor Indonesia, 2009), h. 8.

${ }^{17}$ Jusuf Soewadji, Pengantar Metodologi Penelitian, (Jakarta: Mitra Wacana Media, 2012), h.34.
} 


\section{AL-MARSHAD: JURNAL ASTRONOMI ISLAM DAN ILMU-ILMU BERKAITAN ISSN 2442-5729 (print) || ISSN 2598-2559 (online) \\ http://jurnal.umsu.ac.id/index.php/almarshad \\ DOI: $10.30596 /$ jam.v\%vi\%i.4411 || Vol. 6, No. 1. Juni 2020}

peristiwa alamiah dimana bulan memasuki dalam banyang kerucut bumi. Bayang kerucut bumi ada 2 macam, yaitu bayangan penumbra dan bayangan umbra, bila bulan hanya memasuki wilayah bayangan penumbra disebut gerhana bulan penubra dan bila bulan memasuki zona bayangan umbra disebut gerhana bulan total atau gerhana bulan parsial. ${ }^{18}$ Untuk mengetahui secara mudah dan cepat tentang waktu terjadi gerhana bulan, terdapat sebuah perhitungan yang menurut penulis bisa disebutkan dalam kategori hisab urfi, metode ini penulis ambil dari sebuah buku yang ditulis oleh salah seorang ahli falak dari Aceh bernama Drs. Tgk. H. M. Yusuf Harun yang berjudul Pengantar ilmu falak, buku ini sudah dicetak yang kedua kali pada tahun 2008. Alasan pertama melihat cara perhitungan hanya sekedar untuk mengetahui waktu terjadi gerhana yang masih umum, tidak sampai pada tanggal, waktu, dan wilayah yang terjadi gerhana. Alasan kedua perhitungan masih menggunakan data yang tersusun dalam bentuk tabel dengan cara menambah dan mengurangi. Atas dua alasan ini, penulis menyebutkan kepada perhitungan ini dengan sebutan hisab urfi

\footnotetext{
${ }^{18}$ Muhammad Jayusman, "Fenomena Gerhana Dalam Wacana Hukum Islam dan Astronomi," AL-'ADALAH 10, no. 2 (2011): h. 237-50.
}

gerhana bulan.

Ada tiga langkah yang hasus dilakukan untuk mengetahui gerhana bulan secara hisab urfi. Pertama menyusun sudut gerak gerhana bulan, nilai sudut ini menjadi patrol ada-tidak terjadi gerhana bulan.

Tabel 1, Nilai Sudut Gerak Gerhana Bulan ${ }^{19}$

\begin{tabular}{|r|r|}
\hline \multicolumn{3}{|c|}{ Sudut Gerak Gerhana Bulan } \\
\hline $01^{\circ}$ sampai $14^{\circ}$ \\
\hline $165^{\circ}$ sampai $194^{\circ}$ \\
\hline $345^{\circ}$ sampai $360^{\circ}$ \\
\hline Langkah & kedua adalah menghitung
\end{tabular}

nilai gerak tahunan gerhana bulan, artinya untuk tahun yang ingin diketahui gerhana bulan harus terlebih dahulu dihitung nilai gerak gerhana tahunan, seperti tahun 1444 Hijriah berapa nilai gerak gerhana bulan. Semua nilai gerak tahunan gerhana bulan dan matahari ada dalam tabel berikut:

\footnotetext{
108
} 
Tabel 2, Nilai Gerak Tahunan Gerhana

Matahari dan Bulan ${ }^{20}$

\begin{tabular}{|c|c|c|c|c|c|c|c|}
\hline \multicolumn{7}{|c|}{ Nilai Gerak Tahunan Gerhana Matahari dan } \\
\hline \multicolumn{7}{|c|}{ Bulan } \\
\hline Tahun & $\circ$ & & & Tahun & $\circ$ & & \\
\hline 001 & 008 & 02 & 48 & 1351 & 050 & 33 & 01 \\
\hline 002 & 016 & 05 & 36 & 1381 & 291 & 57 & 01 \\
\hline 003 & 024 & 08 & 24 & 1411 & 173 & 21 & 01 \\
\hline 004 & 032 & 11 & 12 & 1441 & 054 & 45 & 01 \\
\hline 005 & 040 & 14 & 00 & 1471 & 296 & 09 & 01 \\
\hline 006 & 048 & 16 & 48 & 1501 & 177 & 33 & 01 \\
\hline 007 & 056 & 19 & 36 & 1531 & 058 & 57 & 01 \\
\hline 008 & 064 & 22 & 24 & 1561 & 300 & 21 & 01 \\
\hline 009 & 072 & 25 & 12 & 1591 & 181 & 45 & 01 \\
\hline 010 & 080 & 28 & 00 & 1621 & 063 & 09 & 01 \\
\hline
\end{tabular}

Langkah ketiga adalah menghitung nilai gerak gerhana bulanan dalam tahun yang telah ditentukan. Perlu dicatat bahwa hasil perhitungan ini hanya mengimformasikan sebatas ada atau tidak ada gerhana bulan pada saat bulan purnama dalam bulan dan tahun yang dimaksut. Semua nilai gerak gerhana bulanan untuk gerhana matahari dan bulan ada dalam tabel berikut:

\section{h. 108}

${ }^{20}$ M. Yusuf Harun. Pengantar Ilmu Falak.. 
Tabel 3, Nilai Gerak Bulanan Gerhana. ${ }^{21}$

\begin{tabular}{|c|c|c|c|c|c|c|c|}
\hline \multicolumn{8}{|c|}{ Nilai Gerak Bulanan Gerhana Matahari dan Bulan } \\
\hline \multirow{2}{*}{ No } & \multirow{2}{*}{ Nama Bulan } & \multicolumn{3}{|c|}{ Konjungsi Matahari } & \multicolumn{3}{|c|}{ Bulan Purnama } \\
\hline & & $\circ$ & , & $"$ & o & , & " \\
\hline 1 & Muharram & 30 & 47 & 14 & 15 & 20 & 07 \\
\hline 2 & Safar & 61 & 20 & 28 & 46 & 00 & 21 \\
\hline 3 & Rabiul Awal & 92 & 00 & 42 & 76 & 40 & 35 \\
\hline 4 & Rabiul Akhir & 122 & 40 & 56 & 107 & 20 & 49 \\
\hline 5 & Jumadil Awal & 153 & 21 & 10 & 138 & 01 & 03 \\
\hline 6 & Jumadil Akhir & 180 & 01 & 24 & 168 & 10 & 17 \\
\hline 7 & Rajab & 214 & 41 & 38 & 199 & 21 & 31 \\
\hline 8 & Syakban & 245 & 21 & 52 & 230 & 01 & 45 \\
\hline 9 & Ramadhan & 276 & 02 & 06 & 260 & 11 & 59 \\
\hline 10 & Syawal & 306 & 42 & 20 & 291 & 22 & 38 \\
\hline 11 & Zulqaidah & 337 & 22 & 34 & 322 & 02 & 20 \\
\hline 12 & Zulhijjah & 008 & 02 & 48 & 352 & 42 & 41 \\
\hline
\end{tabular}

Inilah tiga langkah yang harus ditempuh dalam menentukan kapan terjadinya gerhana bulan dalam setiap tahun dalam kalender Hijriah. Sebagai contoh, apakah pada saat purnama bulan Ramadhan 1442 $\mathrm{H}$ ada terjadi gerhana bulan? Caranya Menghitung adalah sebagai berikut:

Tentukan nilai gerak tahunan gerhana bulan untuk tahun $1442 \mathrm{H}$, lihat nilai gerak tahunan gerhana bulan pada tabe12. Untuk h. 109.

\footnotetext{
${ }^{21}$ M. Yusuf Hanun. Pengantar Ilmu Falak.
}

$1442 \mathrm{H}$ adalah dengan cara menambahkan nilai tahun $1441 \mathrm{H}$ dengan nilai tahun $001 \mathrm{H}$.

$$
\begin{aligned}
& 1441=054^{\circ} 45^{\prime} 01^{\prime \prime} \\
& 001=008^{\circ} 02^{\prime} 48^{\prime \prime} \\
& =62^{\circ} 47^{\prime} 49^{\prime \prime} \text { ( (ini adalah nilai gerak } \\
& \text { gerhana bulan tahun } 1442 \mathrm{H} \text { ) }
\end{aligned}
$$

Kemudian nilai gerak gerhana tahunan ditambah dengan nilai gerak gerhana bulanan pada purnama bulan Ramadhan sebagaimana tercantum dalam tabel 3, bila hasil penjumlahan melebihi $360^{\circ}$, maka nilai tersebut dikurangi dengan $360^{\circ}$ dan hasilnya merupakan nilai sudut kemungkinan terjadi 


\section{AL-MARSHAD: JURNAL ASTRONOMI ISLAM DAN ILMU-ILMU BERKAITAN ISSN 2442-5729 (print) || ISSN 2598-2559 (online) \\ http://jurnal.umsu.ac.id/index.php/almarshad \\ DOI: $10.30596 /$ jam.v\%vi\%i.4411 || Vol. 6, No. 1. Juni 2020}

gerhana bulan.

$$
\begin{array}{ll}
1442 & =62^{\circ} 47^{\prime} 49^{\prime \prime} \\
\text { Ramadhan } & =260^{\circ} 11^{\prime} 59^{\prime \prime} \\
& =322^{\circ} 59^{\prime} 48^{\prime \prime} .
\end{array}
$$

Selanjutnya nilai ini dilihat apa ada masuk da lam salah satu rentang nilai sudut gerak gerhana bulan dalam tabel 1 . Ternyata nilai $322^{\circ} 59^{\prime} 48^{\prime \prime}$ tidak termasuk dalam salah satu rentang sudut gerak gerhana bulan, berarti purnama bulan Ramadhan 1442 H tidak ada gerhana bulan.

Contoh lain untuk purnama bulan Syawal 1443 H. Cara menghitung adalah sebagai berikut:

$$
\begin{aligned}
& 1441=054^{\circ} 45^{\prime} 01^{\prime \prime} \\
& 002=016^{\circ} 05^{\prime} 36^{\prime \prime} \\
& =70^{\circ} 50^{\prime} 37^{\prime \prime}(1443 \mathrm{H})
\end{aligned}
$$$$
1443 \mathrm{H}+\text { Syawal }=70^{\circ} 50^{\prime} 37^{\prime \prime}+
$$

$291^{\circ} 22^{\prime} 38^{\prime \prime}$

$=362^{\circ} 13^{\prime} 15^{\prime \prime}-360^{\circ}=02^{\circ} 13^{\prime} 15^{\prime \prime}$

(nilai sudut gerak gerhana bulan).

Ternyata nilai $02^{\circ} 13^{\prime} 15^{\prime \prime}$ masuk dalam rentang sudut gerhana bulan $01^{\circ}$ sampai $14^{\circ}$. Jadi bisa disimpulkan bahwa saat purnama bulan Syawal $1443 \mathrm{H}$ ada terjadi gerhana bulan.

Berdasarkan pada metode tersebut, semua orang bisa dengan mudah dan cepat melakukan pengecekan terhadap kemungkinan terjadi gerhana bulan di setiap bulan dalam setiap tahun Hijriah

\begin{tabular}{|c|c|c|c|c|c|c|}
\hline \multicolumn{7}{|c|}{$\begin{array}{r}\text { Nilai Gerak Gerhana Bulan } \\
25 "\end{array}$} \\
\hline \multirow[t]{2}{*}{ No } & \multirow[t]{2}{*}{$\begin{array}{l}\text { Nama } \\
\text { Bulan }\end{array}$} & \multicolumn{3}{|c|}{$\begin{array}{c}\text { Nilai Sudut } \\
\text { Gerak gerhana } \\
\text { bulan }\end{array}$} & \multicolumn{2}{|c|}{ Hasil } \\
\hline & & O & & " & Ada & Tidak \\
\hline 1 & Muharram & 94 & 13 & 32 & - & Tidak \\
\hline 2 & Safar & 124 & 53 & 46 & - & Tidak \\
\hline 3 & $\begin{array}{l}\text { Rabiul } \\
\text { Awal }\end{array}$ & 155 & 34 & 00 & - & Tidak \\
\hline 4 & $\begin{array}{l}\text { Rabiul } \\
\text { Akhir }\end{array}$ & 186 & 14 & 14 & Ada & - \\
\hline 5 & $\begin{array}{l}\text { Jumadil } \\
\text { Awal }\end{array}$ & 216 & 54 & 28 & - & Tidak \\
\hline 6 & $\begin{array}{l}\text { Jumadil } \\
\text { Akhir }\end{array}$ & 247 & 03 & 42 & - & Tidak \\
\hline 7 & Rajab & 278 & 14 & 56 & - & Tidak \\
\hline 8 & Syakban & 308 & 55 & 10 & - & Tidak \\
\hline 9 & Ramadhan & 339 & 05 & 24 & - & Tidak \\
\hline 10 & Syawal & 10 & 16 & 03 & Ada & - \\
\hline 11 & Zulqaidah & 40 & 55 & 45 & - & Tidak \\
\hline 12 & Zulhijjah & 71 & 36 & 06 & - & Tidak \\
\hline
\end{tabular}

yang diinginkan. Sebagai contoh, berikut hasil perhitungan dalam menjaring jumlah gerhana bulan yang akan terjadi dalam tahun $1444 \mathrm{H}$. Tabel 4, Perkiraan waktu terjadi gerhana bulan tahun $1444 \mathrm{H}$.

Berdasarkan nilai sudut gerak gerhana bulan dalam tabel 4 dapat disimpulkan bahwa pada tahun $1444 \mathrm{H}$ akan terjadi 2 kali gerhana bulan, yaitu pada purnama bulan Rabiul Akhir $1444 \mathrm{H}$ dan purnama bulan Syawal $1444 \mathrm{H}$. Ternyata kesimpulan ini juga sesuai dengan data gerhana bulan yang disusun oleh Rinto 


\section{AL-MARSHAD: JURNAL ASTRONOMI ISLAM DAN ILMU-ILMU BERKAITAN ISSN 2442-5729 (print) || ISSN 2598-2559 (online) \\ http://jurnal.umsu.ac.id/index.php/almarshad \\ DOI: $10.30596 /$ jam.v\%vi\%i.4411 || Vol. 6, No. 1. Juni 2020}

Anugraha dalam bukunya "Mekanika Benda Langit" yang menggunakan algoritma Meeus, yaitu gerhana bulan total akan terjadi pada tanggal 8 November 2022/purnama Rabiul Akhir 1444 H dan gerhana bulan penumbra tanggal 5 Mei 2023/purnama Syawal 1444 H. $^{22}$ Setelah menjaring de ngan metode hisab urfi untuk gerhana bulan dan ditemukan dua kali terjadi gerhana bulan, untuk langkah berikutnya dalam mengetahui awal dan ahir gerhana bulan, jenis gerhana bulan, dan lokasi yang bisa menyaksikan gerhana bulan harus menggunakan hisab hakiki dengan menggunakan algoritma yang mapan, metode hisab urfi ini hanya bisa digunakan untuk penjaringan awal saja.

\section{His ab Urfi Ge rhana Matahari}

Untuk mengetahui peristiwa gerhana matahari secara hisab urfi juga menggunakan metode yang sama dengan langkah-langkah menghitung sperti pada gerhana bulan. Langkah pertama adalah menyusun sudut gerak gerhana matahari sebagai berikut:
Tabel 5, Nilai Sudut Gerak Gerhana Matahari ${ }^{23}$

\begin{tabular}{|r|r|}
\hline Sudut Ge rak Gerhana Matahari \\
\hline $01^{\circ}$ & sampai $20^{\circ}$ \\
\hline $159^{\circ}$ & sampai $190^{\circ}$ \\
\hline $348^{\circ}$ & sampai $360^{\circ}$ \\
\hline Langkah & kedua ada lah menghitung
\end{tabular}

nilai gerak tahunan gerhana matahari untuk tahun yang hendak diketahui gerhana matahari dengan berpedoman pada nilai gerak tahunan gerhana matahari yang ada dalam tabel No 2 . Langkah ketiga adalah menghitung nilai gerak bulanan gerhana matahari sebagaiman tersusun dalam tabel No 3 dengan cara menambahkan nilai sudut gerak tahunan dengan gerak bulanan, namun perlu dicatat bahwa nilai gerak bulanan yang diambil dalam tabel No 3 untuk mengetahui gerhana matahari adalah nilai konjungsi matahari, bukan nilai bulan purnama. Hal ini dikarenakan gerhana matahari hanya terjadi saat konjungsi dan gerhana bulan hanya terjadi saat fase purnama.

Sebagai contoh, untuk konjungsi bulan Rabiul Akhir 1442 H apakah ada terjadi gerhana matahari atau tidak. Langkah pertama menghitung nilai gerak tahunan gerhana matahari untuk tahun $1442 \mathrm{H}$ dengan cara menambahkan nilai gerak gerhana tahun 1441 $\mathrm{H}$ dengan nilai gerak gerhana tahun 001 .

$$
\begin{aligned}
& 1441=054^{\circ} 45^{\prime} 01^{\prime \prime} \\
& 001=008^{\circ} 02^{\prime} 48^{\prime \prime}
\end{aligned}
$$
Langit. Hal. 183-184.

${ }^{22}$ Rinto Anugraha, Mekanika Benda Copyright C2020. Al-Marshad: JumalAstronomi Islam danIlmu-IlmuBerkaitan. This is an open acces article under the CC-BY-SA lis ence (https://creativecommons .org/licens es/by-sa/4.0/). 


\section{AL-MARSHAD: JURNAL ASTRONOMI ISLAM DAN ILMU-ILMU BERKAITAN ISSN 2442-5729 (print) || ISSN 2598-2559 (online) \\ http://jurnal.umsu.ac.id/index.php/almarshad \\ DOI: $10.30596 /$ jam.v\%vi\%i.4411 || Vol. 6, No. 1. Juni 2020}

$=62^{\circ} 47^{\prime} 49^{\prime \prime}$. (ini ada lah nilai gerak

gerhana matahari tahun $1442 \mathrm{H}$ )

Kemudian nilai gerak gerhana tahunan ditambah dengan nilai gerak gerhana matahari bulanan pada konjungsi matahari bulan Rabiul Akhir sebagai mana tercantum dalam tabel 3 , bila hasil penjumlahan melebihi $360^{\circ}$, maka nilai tersebut dikurangi dengan $360^{\circ}$ dan hasilnya merupakan nilai sudut kemungkinan terjadi gerhana bulan.

$$
\begin{array}{ll}
1442 & =62^{\circ} 47^{\prime} 49^{\prime \prime} \\
\text { Syawal } & =122^{\circ} 40^{\prime} 56^{\prime \prime} \\
& =185^{\circ} 28^{\prime} 45^{\prime \prime} \text { (nilai }
\end{array}
$$

sudut gerak gerhana matahari)

Ternyata nilai sudut gerak gerhana matahari $185^{\circ} 28^{\prime} 45^{\prime \prime}$ cocok dengan salah satu rentang nilai sudut gerhana matahari, yaitu sudut $159^{\circ}$ sampai $190^{\circ}$. Jadi bisa dis impulkan bahwa saat ahir bulan Rabiul Akhir $1442 \mathrm{H}$ ada terjadi gerhana matahari. Ternyata hasil ini juga cocok dengan data gerhana matahari yang dipublikasikan oleh NASA, dimana aka terjadi gerhana matahari total pada tanggal 14 Desember 2020 yang bertepatan pada saat konjungsi bulan Rabiul Akhir dengan bulan Jumadil Awal 1442 H. $^{24}$

Contoh lain untuk konjungsi bulan Syawal $1443 \mathrm{H}$, cara menghitungnya

\footnotetext{
${ }^{24}$ NASA, "NASA - Solar Eclipse Page," diakses 4 Maret 2020.
}

adalah sebagai berikut:

$$
\begin{aligned}
& 1441=054^{\circ} 45^{\prime} 01^{\prime \prime} \\
& 002=016^{\circ} 05^{\prime} 36^{\prime \prime} \\
& =70^{\circ} 50^{\prime} 37^{\prime \prime}(1443 \mathrm{H}) \\
& 1443 \mathrm{H}+\text { Syawal }=70^{\circ} 50^{\prime} 37^{\prime \prime}+306^{\circ}
\end{aligned}
$$

42' 20 "

$$
=377^{\circ} 32^{\prime} 57^{\prime \prime}-360^{\circ}=17^{\circ} 32^{\prime} 57^{\prime \prime}
$$

(nilai sudut gerak gerhana matahari).

Ternyata nilai sudut gerhana matahari $17^{\circ} 32^{\prime}$ '57" ada yang cocok dengan salah satu rentang sudut gerhana matahari, yaitu rentang $01^{\circ}$ sampai $20^{\circ}$. Jadi pada ahir bulan Syawal $1443 \mathrm{H}$ ada terjadi gerhana matahari. Bila dicocokkan dengan data NASA, ternyata yang terjadi adalah gerhana matahari parsial pada tanggal 30 April 2022 yang bertepatan saat konjungsi bulan Syawal dengan bulan Ramadhan $1443 \mathrm{H}$, bukan saat konjungsi bulan Syawal dengan bulan Zulqaidah $1443 \mathrm{H}$. Artinya, gerhana matahari tidak terjadi pada ahir bulan Syawal tetapi terjadi pada awal Syawal $1443 \mathrm{H}^{25}$ Dari dua contoh perhitungan tersebut dapat disimpulkan bahwa terjadi gerhana tidak selalu tetap pada ahir bulan dimana nilai gerak bulanan gerhana matahari diambil seperti yang terjadi pada contoh perhitungan bulan Rabiul Akhir $1442 \mathrm{H}$, bisa juga gerhana terjadi pada awal bulan seperti pada contoh perhitungan gerhana matahari bulan Syawal $1443 \mathrm{H}$, dimana gerhana

${ }^{25}$ NASA, "NASA -Solar Eclipses: 20212030," diakses 4 Maret 2020. 


\section{AL-MARSHAD: JURNAL ASTRONOMI ISLAM DAN ILMU-ILMU BERKAITAN ISSN 2442-5729 (print) || ISSN 2598-2559 (online) \\ http://jurnal.umsu.ac.id/index.php/almarshad \\ DOI: $10.30596 /$ jam.v\%vi\%i.4411 || Vol. 6, No. 1. Juni 2020}

matahari terjadi pada awal bulan Syawal bukan pada ahir bulan Syawal $1443 \mathrm{H}$. Ketidak pastian terjadi gerhana matahari disetiap ahir bulan dimana data gerak bulanan gerhana matahari diambil menyebabkan cara hisab urfi ini jauh dari kesempurnaan dalam memberikan informasi waktu terjadinya gerhana, karena kemungkinan terjadi gerhana matahari pada awal bulan atau ahir bulan bisa selisih waktu 29 atau 30 hari.

Kesimpulan ini telah penulis uji dalam menghitung penjaringan kemungkinan terjadi gerhana matahari untuk 5 tahun, yaitu tahun $1442 \mathrm{H}, 1443$ H, $1444 \mathrm{H}, 1445 \mathrm{H}$, dan $1446 \mathrm{H}$. Hasil perhitungan dengan hisab urfi menunjuki pada tahun $1442 \mathrm{H}$ terjadi 2 kali gerhana matahari, yaitu ahir bulan Rabiul Akhir dan ahir bulan Syawal 1442 H. Pada tahun $1443 \mathrm{H}$ ada terjadi juga 2 kali gerhana matahari, yaitu ahir bulan Rabiul Awal dan ahir bulan Syawal 1443 H, namun setelah dicocokkan dengan data NASA ternyata gerhana matahari memang ada terjadi 2 kali pada tahun $1443 \mathrm{H}$, namun tidak pada ahir bulan Rabiul Awal dan ahir bulan Syawal, tetapi gerhana matahari terjadi pada ahir bulan Rabiul Akhir $1443 \mathrm{H}$ dan pada awal bulan Syawal 1443 H. Pada tahun $1444 \mathrm{H}$ juga terdapat 2 kali gerhana matahari, yaitu ahir bulan Rabiul Awal
$1444 \mathrm{H}$ dan ahir bulan Ramadhan $1444 \mathrm{H}$. Tahun 1445 terdapat 2 kali gerhana matahari, yaitu ahir bulan Rabiul Awal 1445 H dan ahir bulan Ramadhan 1445 H. Dalam tahun 1446 $\mathrm{H}$ juga terdapat 2 kali gerhana matahari, yaitu ahir bulan Rabiul Awal 1446 H dan ahir bulan Ramadhan $1446 \mathrm{H}$.

Kasus yangjanggal dari 5 tahun tersebut hanya terjadi pada perhitungan gerhana matahari untuk bulan Rabiul Awal $1443 \mathrm{H}$ yang tidak terjadi gerhana matahari pada ahir bulan Rabiul Akhir $1443 \mathrm{H}$ perlu untuk didalami lebih dalam lagi untuk menemukan penyebab kekeliruan dalam proses perhitungan. Penulis belum mampu menemukan penyebab kejanggalan ini.Berikut perhitungannya untuk perkiraan gerhana matahari saat konjungsi bulan Rabiul Awal $1443 \mathrm{H}$ :

$$
\begin{aligned}
& 1441=054^{\circ} 45^{\prime} 01^{\prime \prime} \\
& 002=016^{\circ} 05^{\prime} 36^{\prime \prime} \\
& =70^{\circ} 50^{\prime} 37^{\prime \prime}(1443 \mathrm{H}) \\
& 1443 \mathrm{H}+\text { Rabiul Awal = } 70^{\circ} 50^{\prime} 37^{\prime \prime}+
\end{aligned}
$$
$92^{\circ} 00^{\prime} 42^{\prime \prime}$

$=162^{\circ} 51^{\prime} 19^{\prime \prime}$ (nilai sudut gerak gerhana matahari).

Seharusnya, karena nilai sudut gerak gerhana matahari $162^{\circ} 51^{\prime} 19^{\prime \prime}$ cocok dengan salah satu rentang nilai sudut gerhana matahari, yaitu sudut $159^{\circ}$ sampai $190^{\circ}$, maka gerhana matahari akan terjadi pada ahir bulan Rabiul Awal 1443 H. Namun setelah dilihat 


\section{AL-MARSHAD: JURNAL ASTRONOMI ISLAM DAN ILMU-ILMU BERKAITAN ISSN 2442-5729 (print) || ISSN 2598-2559 (online) \\ http://jurnal.umsu.ac.id/index.php/almarshad \\ DOI: 10.30596/jam.v\%vi\%i.4411 || Vol. 6, No. 1. Juni 2020}

data gerhana matahari yang ada pada web NASA ternyata gerhana matahari total terjadi pada tanggal 4 Desember $2021^{26}$ yang bertepatan saat konjungsi bulan Rabiul Akhir dengan Jumadil Awal 1443 H. Artinya gerhana matahari terjadi pada ahir bulan Rabiul Akhir 1443 H bukan pada ahir bulan Rabiul Awal $1443 \mathrm{H}$.

\section{Kesimpulan}

Dari uraian di atas dapat disimpulkan bahwa metote hisab urfi gerhana bulan dan gerhana matahari yang terdapat dalam buku "Pengantar Ilmu Falak" karangan M. Yusuf Harun sangat akurat untuk mengetahui jaumlah gerhana bulan dan gerhana matahari yang akan terjadi dalam setiap tahun Hijriah. Sebagai contoh yang telah penulis hitung, untuk tahun $1442 \mathrm{H}$ ada 2 kali terjadi gerhana matahari dan ada 2 kali terjadi gerhana bulan. Tahun $1443 \mathrm{H}$ juga ada 2 kali terjadi gerhana matahari dan ada 2 kali terjadi gerhana bulan. Tahun $1444 \mathrm{H}$ juga ada 2 kali terjadi gerhana matahari dan 2 kali terjadi gerhana bulan. Tahun $1445 \mathrm{H}$ juga terjadi 2 kali gerhana matahari dan 2 kali gerhana bulan. Dalam tahun $1446 \mathrm{H}$ juga terjadi 2 kali gerhana matahari dan 2 kali gerhana bulan. Jumlah ini juga cocok bila dibandingkan dengan data gerhana bulan dan matahari yang disusun oleh Lembaga NASA dan Bapak Rinto Anugraha dalam bunya "Mekanika Benda Langit".

Untuk waktu terjadinya gerhana bulan juga sangat akurat, artinya bisa langsung disampaikan pada setiap bulan purnama yang secara perhitungan hisab urfi ini ada terjadi gerhana bulan. Namun untuk gerhana matahari tidak bisa langsung diinformasikan setiap akhir bulan yang secara perhitungan hisab urfi ini ada terjadi gerhana matahari, hal ini karena ada satu kasus yang ditemukan dalam penjaringan gerhana matahari $1443 \mathrm{H}$ gerhana matahari terjadi pada awal bulan yang dihitungkan dan bahkan ada satu kasus tidak terjadi gerhana matahari pada bulan yang secara perhitungan ada terjadigerhana matahari. Kejadian gerhananya meleset 1 bulan karena terjadi pada ahir bulan berikutnya. Walaupun demikian, metote hisab urfi gerhana matahari dan bulan ini perlu apresiasi, dikaji dan disebarluaskan karena cara perhitungan yang mudah sangat cocok bagi pemula studi ilmu falak dan untuk menghapus is u bahwa peristiwa gerhana selama ini sudah sering terjadi ketimbang di zaman dulu.

\section{${ }^{26}$ NASA.}




\section{AL-MARSHAD: JURNAL ASTRONOMI ISLAM DAN ILMU-ILMU BERKAITAN ISSN 2442-5729 (print) || ISSN 2598-2559 (online) \\ http://jurnal.umsu.ac.id/index.php/almarshad \\ DOI: $10.30596 /$ jam.v\%vi\%i.4411 || Vol. 6, No. 1. Juni 2020}

\section{Daftar Pus taka}

Alimuddin, Alimuddin. 2016. "Gerhana Matahari Di Abad 21." Al Daulah: Jurnal Hukum Pidana Dan Ketatanegaraan 5, no. 2: 427-43. https://doi.org/10.24252/ad.v5i2.4859.

Alyasyfi, Muhammad Najib, Dwi Gusrianti, Robby Salam, Rizky Kurniawan, Fahmi Juliansyah, dan Muhamad Gina Nugraha. 2016. "Pengaruh Perubahan Intensitas Cahaya Akibat Gerhana Matahari Sebagian Terhadap Gerak Daun Bauhinia Purpurea." Prosiding Seminar Nasional Fisika (EJOURNAL) 5 SNF2016-BMP-3944.https ://doi. org/10.21009/03050203 08 .

Azmi, Muhammad Farid. 2018. "Prediksi

Pergerakan Bayangan Bumi Saat Terjadi Gerhana Bulan Menggunakan Ephemeris Hisab Rukyat." $A l$ Marshad: Jurnal Astronomi Islam dan Ilmu-Ilmu Berkaitan 4, no. 2 https://doi.org/10.30596/jam.v4i2.214 0.

Bungaran Antonius Simanjuntak dan Soedjito Sosrodihardjo, 2009. Metode
Penelitian Sosial, (Jakarta: Yayasan Pustaka Obor Indonesia,), hlm. 8.

Hamdani, Fahmi Fatwa Rosyadi Satria, Encep Abdul Rojak, dan Maulan Rif'atul Wafy. 2019 "Fikih Salat Gerhana Menurut Imam Ibnu Hajar Al-Haitami." Al-Marshad: Jurnal Astronomi Islam Dan Ilmu-Ilmu $\begin{array}{llll}\text { Berkaitan } & 5, & \text { no. } & 1\end{array}$ https://doi.org/10.30596/jam.v5i1.3123.

Hidayat, Ehsan. 2019. "Penentuan Jumlah Gerhana Matahari Dengan Argumen Lintang Bulan Dan Teori Aritmatika." Miyah : Jurnal Studi Islam 15, no. 01 1242.

Ilham, M, Hendro Moro, an Dahlan. 2016. "Perilaku Ayam Mutiara (Numida melegris, Linn 1758) pada saat Gerhana Matahari Sebagian di Jogjakarta,"

Jusuf Soewadji, 2012. Pengantar Metodologi Penelitian, Jakarta: Mitra Wacana Media.

LAPAN. 2016. The Eclipse Gerhana Matahari Total (Catatan Peristiwa 9 Maret 2016). Jakarta: LAPAN.

M. Yusuf Harun. 2008. Pengantar Ilmu Falak. Banda Aceh: PeNA.

Muhajir, Muhajir. 2019. "Sistem Hisab Gerhana Bulan Kh. Noor Ahmad Ss 


\section{AL-MARSHAD: JURNAL ASTRONOMI ISLAM DAN ILMU-ILMU BERKAITAN ISSN 2442-5729 (print) || ISSN 2598-2559 (online) \\ http://jurnal.umsu.ac.id/index.php/almarshad \\ DOI: $10.30596 /$ jam.v\%vi\%i.4411 || Vol. 6, No. 1. Juni 2020}

Dalam Kitab Nûr Al-Anwâr.” Jurnal Islam Nusantara 3, no. 2 456-75. https://doi.org/10.33852/jurnalin.v3i2. 149.

Muhammad Jayusman. 2011. "Fenomena Gerhana Dalam Wacana Hukum Islam dan Astronomi." AL-'ADALAH 10, no. $2: 237-50$.

Mukarromah, Siti Lailatul. 2019 "Perhitungan Gerhana Matahari Dengan Algoritma NASA." Ulul Albab: Jurnal Studi Dan Penelitian Hukum Islam 2, no. 2: 99 113.https://doi.org/10.30659/jua.v2i2. 3642

NASA. "NASA - Solar Eclipse Page." Diakses 4 Maret 2020. https://eclipse.gsfc.nasa.gov/solar.html

NASA "NASA - Solar Eclipses: 2021 2030.” Diakses 4 Maret 2020. https://eclipse.gsfc.nasa.gov/SEdecade /SEdecade2021.html.

Rinto Anugraha. 2012. Mekanika Benda Langit. Yogyakarta: MIPA UGM.

Sulaiman, Rusydi. 2017. "Gerhana Dan Keharusan Kosmologis Manusia: Tinjauan Filsafat Wujud.” Edugama:
Jurnal Kependidikan Dan Sosial Keagamaan 3, no. 2 104-26. https://doi.org/10.32923/edugama.v3i2.72 5.

Toni Kus Indratno, Ginanjar A. Muhammad, dan Widiyaka Adinugraha. 2016. "Pengaruh Gerhana Matahari Terhadap Nilai Percepatan Gravitasi Bumi: Sarana Pembelajaran untuk Mendekatkan Fisika pada Kehidupan Sehari-hari” 3, no. 1 1012.

Yaqin, Ahmad Ainul, dan Fahmi Fatwa Rosyadi Satria Hamdani. 2018 "Hadis Gerhana Dan Wafatnya Ibrahim Ibn Muhammad." Tahkim (Jurnal Peradaban dan Hukum Islam) 1, no. 1 https://doi.org/10.29313/tahkim.v1i1.3349 Zaman, Qomaruz. 2016. "Gerhana Dalam Perspektif Hukum Islam Dan Astronomi.” Empirisma: Jurnal Pemikiran Dan Kebudayaan Islam 25, no. 2 https://doi.org/10.30762/empiris ma.v25i2. 299. 